\title{
Biochar, Filter-Cake, and Polymer-Based Special Fertilizers for Maize Cultivation
}

\author{
Miguel Henrique Rosa Franco ${ }^{1}$, Regina Maria Quintão Lana ${ }^{1}$, Reginaldo de Camargo ${ }^{1}$, \\ Camila Andrade de Carvalho Gualberto ${ }^{1} \&$ André Cabral França $^{2}$ \\ ${ }^{1}$ Federal University of Uberlândia, Uberlândia, Brazil \\ ${ }^{2}$ Federal University of the Vales do Jequitinhonha e Mucuri, Brazil \\ Correspondence: Miguel Henrique Rosa Franco, Agrarian Science Department, Federal University of Uberlândia, \\ Uberlândia, Rua Machado de Assis, n. 45, Ap 202, Centro, CEP 38600-454, Paracatu, MG, Brazil. Tel: \\ 55-38-992-065-919. E-mail: miguelmhrf@yahoo.com.br
}

Received: January 19, 2020

Accepted: February 18, 2020

Online Published: March 15, 2020

doi:10.5539/jas.v12n4p208

URL: https://doi.org/10.5539/jas.v12n4p208

\begin{abstract}
This investigation assessed the effects of special fertilizers on maize. The experiment was performed according to a randomized block design, with four replications in a $7 \times 4+1$ factorial scheme, representing seven sources (filter-cake-based organic compound, biochar-based organic compound, organic-mineral (OM) filter-cake, OM biochar, OM filter cake + humic substances (HS), mineral fertilizer with polymers, and conventional mineral) and four fertilizer levels based on the nitrogen (N) contents (60, 120, 180, and $240 \mathrm{~kg} / \mathrm{ha}$ ). An absolute control, without any fertilizer application, was used. At 60 days after sowing (DAS), the plant growth parameters, nutritional status, and residual nutrients in the soil were evaluated. The mineral fertilizer with polymers and OM filter-cake + HS showed better results for the dry matter of the shoot of the plant and plant height. When considering the leaf area, the OM filter-cake and OM filter-cake + HS fertilizers stood out. The accumulation of $\mathrm{N}$ and potassium $(\mathrm{K})$ in the shoot of the plants was higher when the OM filter-cake + HS and mineral fertilizer with polymers were applied. With respect to the accumulated phosphorus (P), treatment with the OM filter-cake, OM filter-cake + HS, and mineral with polymers showed better results. On the other hand, for the analysis of P and residual $\mathrm{K}$ in the soil, the treatments based on filter-cake and biochar organic compost were better. Treatment with the OM filter-cake + HS and mineral with polymers stood out when considering the plant growth parameters and nutritional aspects of the maize crop.
\end{abstract}

Keywords: efficiency, humic substances, organic-mineral

\section{Introduction}

The use of organic-mineral and organic fertilizers is an alternative to counter increasing national grain production (Polidoro, 2013) and structural deficiencies of Brazilian soils.

Organic-mineral fertilizers are formulated from organic waste, such as manure, peat, residues from the sugar industry, residues from the alcohol industry, bone meal, different cakes, agribusiness waste, and sewage sludge. Therefore, the use of these residues to produce organic-mineral fertilizers can immediately eliminate 50 percent of the environmental liabilities generated by these production processes by 2020 (Benites et al., 2010).

Another way to enhance this market and the technology involved in the manufacture of fertilizers is related to the study of alternatives capable of improving the physicochemical characteristics of these products. Some alternatives, such as the addition of isolated humic substances (humic and fulvic acids), introduction of the organic matrix pyrolysis process, biochar production, and manufacture of special fertilizers with the addition of polymers, have been studied with the aim to improve the agronomic features of these fertilizers.

According to Rocha et al. (2003), humic substances can modify plant metabolism due to their effects on the soil, such as metal complexation, increased cation exchange capacity, nutrient supply, and moisture retention. These substances can also influence ion transport, respiratory activity, chlorophyll content, nucleic acid synthesis, and the activity of various enzymes in plants, thus favouring better plant development (Nannipieri et al., 1983).

Studies have found that the application of biochar to the soil makes a significant contribution to the physical nature of the system, influencing the structure, texture, porosity, depth, and consistency of soils, due to changes 
in the surface area density and pore and particle distribution, density, and size (Van Zwietwn et al., 2010).

The major advantages of polymer-coated fertilizers are the use of this protective layer against agents that cause nutrient loss and the behavioural change of these encapsulated fertilizers in relation to conventional sources, which promote a gradual availability of mineral elements to the system (Silva et al., 2012).

In this study, the objective was to evaluate the use of different types of special fertilizers for maize compared to the use of a conventional mineral fertilizer.

\section{Materials and Methods}

The experiment was performed in a greenhouse at the Federal University of Uberlândia, Umuarama campus, from January to April 2018, in plastic pots with approximately $18 \mathrm{~kg}$ of soil. Dystrophic Red Latosol (LVd), collected from the experimental farm of Gloria, Uberlândia-MG, was used. The soil was sieved through a $4 \mathrm{~mm}$ mesh, and dolomitic limestone with $90 \%$ relative power of total neutralization (PRNT), containing approximately $460 \mathrm{mg} / \mathrm{g}$ calcium oxide $(\mathrm{CaO})$ and $80 \mathrm{mg} / \mathrm{g}$ magnesium oxide $(\mathrm{MgO})$, was added at $18 \mathrm{~g}$ per pot. The samples were subsequently incubated for a period of 60 days, to correct the acidity and increase the base saturation to $60 \%$. The chemical and physical compositions of the soil used in the experiment after the limestone application and incubation are described in Table 1, the analyses being carried out according to the methodologies proposed by Embrapa (2009) and Embrapa (1997).

Table 1. Chemical and physical characterization of the soil after limestone application and incubation for 60 days

\begin{tabular}{|c|c|c|c|c|c|c|c|c|}
\hline \multicolumn{9}{|c|}{ Chemical analysis } \\
\hline $\mathrm{pH}\left(\mathrm{H}_{2} \mathrm{O}\right)$ & $\mathrm{Ca}$ & $\mathrm{Mg}$ & $\mathrm{Al}$ & $\mathrm{P}$ & $\mathrm{K}$ & $\mathrm{H}+\mathrm{Al}$ & CTC & $\mathrm{S}-\mathrm{SO}_{4}$ \\
\hline $1-2.5$ & \multicolumn{3}{|c|}{------------- $\mathrm{cmol}_{\mathrm{c}} / \mathrm{dm}^{3}$------------ } & $-\cdots$ & $\mathrm{dm}^{3}-\cdots--$ & \multicolumn{2}{|c|}{-------- $\mathrm{cmol}_{\mathrm{c}} / \mathrm{dm}^{3}$------- } & $\mathrm{mg} / \mathrm{dm}^{3}$ \\
\hline 6.7 & 1 & 0.5 & 0 & 1 & 20 & 1.7 & 3.25 & 41 \\
\hline M.O. & C.O. & $\mathrm{B}$ & $\mathrm{Cu}$ & $\mathrm{Fe}$ & $\mathrm{Mn}$ & $\mathrm{Zn}$ & $\mathrm{V}$ & $\mathrm{m}$ \\
\hline \multicolumn{7}{|c|}{----------- dag/kg ------------- } & \multicolumn{2}{|c|}{ 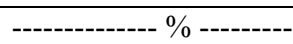 } \\
\hline 0.6 & 0.4 & 0 & 0.7 & 9 & 2.4 & 0.5 & 58 & 0 \\
\hline \multicolumn{9}{|c|}{ Textural Analysis } \\
\hline \multirow[t]{2}{*}{ Soil } & \multicolumn{2}{|c|}{ Coarse sand } & \multicolumn{2}{|l|}{ Fine sand } & Silt & & \multicolumn{2}{|l|}{ Clay } \\
\hline & \multirow{2}{*}{\multicolumn{4}{|c|}{297}} & & & & \\
\hline $\mathrm{LVd}$ & & & & & 54 & & 400 & \\
\hline
\end{tabular}

Note. $\mathrm{Ca}, \mathrm{Mg}$, and $\mathrm{Al}=1 \mathrm{~mol} \mathrm{KCl} / \mathrm{L} ; \mathrm{P}$ and $\mathrm{K}=\mathrm{HCl} 0.05 \mathrm{~mol} / \mathrm{L} \mathrm{HCl}+\mathrm{H}_{2} \mathrm{SO}_{4} 0.0125 \mathrm{~mol} / \mathrm{L} ;$ Available- $\mathrm{P}$ (Mehlich-1 extractor); $\mathrm{S}=$ calcium phosphate $0.01 \mathrm{~mol} / \mathrm{L} ; \mathrm{H}+\mathrm{Al}=$ Buffer Solution-SMP at $\mathrm{pH}$ 7.5; $\mathrm{Cu}, \mathrm{Fe}$, $\mathrm{Mn}$, and $\mathrm{Zn}=$ DTPA $0.005 \mathrm{~mol} / \mathrm{L}+$ TEA $0.1 \mathrm{~mol}^{-1}+\mathrm{CaCl}_{2} 0.01 \mathrm{~mol} / \mathrm{L}$ at $\mathrm{pH} 7.3, \mathrm{cmolc} / \mathrm{dm}^{3} \times 10=$ $\left(\mathrm{mmolc} / \mathrm{dm}^{3}\right) /\left(\mathrm{mg} / \mathrm{dm}^{3}\right)=\mathrm{ppm} / \mathrm{dag} / \mathrm{kg}=\% \mathrm{CTC}$ at $\mathrm{pH} 7.0 ; \mathrm{V}=$ Base saturation; $\mathrm{m}=$ Aluminum saturation; M.O. = Colorimetric Method; Methodologies based on EMBRAPA (2009). Textual Analysis conducted using the Pipette Method (EMBRAPA, 1997).

The experiment was performed according to a randomized block design with four replications in a $7 \times 4+1$ factorial scheme, corresponding to seven sources (filter-cake-based organic compound, biochar-based organic compound, organic-mineral (OM) filter-cake, OM biochar, OM filter-cake + humic substances (HS), mineral fertilizer with polymers, and conventional mineral) and 4 fertilizer levels based on the nitrogen $(\mathrm{N})$ contents (60, 120,180 , and $240 \mathrm{~kg} / \mathrm{ha}$ ). An absolute control, without any fertilizer application, was used. Due to the similarity between phosphorus $(\mathrm{P})$ and potassium $(\mathrm{K})$ levels in organic-mineral and mineral fertilizers, treatments with these fertilizers received the same doses of these nutrients. However, the doses of $\mathrm{P}$ and $\mathrm{K}$ in organic fertilizers were different. Thus, the doses of the biochar and cake treatments were calculated considering the $\mathrm{N}$ content (\%) present in these organic materials, fixing this element as a basis for calculating the dose to be applied and presenting variations in the $\mathrm{P}$ and $\mathrm{K}$ doses, as shown in Table 2. 
Table 2. Type of fertilizer, amount of nutrients, and sources of each treatment

\begin{tabular}{|c|c|c|c|c|c|c|}
\hline \multirow{2}{*}{ Source } & \multicolumn{3}{|c|}{ Doses } & \multirow{2}{*}{ Dose in the soil } & \multirow{2}{*}{ Source dose } & \multirow{2}{*}{ Source dose } \\
\hline & $\mathrm{P}_{2} \mathrm{O}_{5}$ & $\mathrm{~N}$ & $\mathrm{~K}_{2} \mathrm{O}$ & & & \\
\hline & \multicolumn{4}{|c|}{  } & --- g/plant --- & -- g/kg soil -- \\
\hline No fertilizer added & 0 & 0 & 0 & 0 & 0 & 0 \\
\hline \multirow{4}{*}{ Organic meal-based filter-cake (cake) } & 96 & 60 & 48 & 12000 & $108.0^{*}$ & 6.0 \\
\hline & 192 & 120 & 96 & 24000 & $216.0^{*}$ & 12.0 \\
\hline & 288 & 180 & 144 & 36000 & $324.0^{*}$ & 18.0 \\
\hline & 384 & 240 & 192 & 48000 & $432.0^{*}$ & 24.0 \\
\hline \multirow{4}{*}{ Organic meal-based biochar (biochar) } & 75 & 60 & 45 & 15000 & $135.0^{*}$ & 7.5 \\
\hline & 150 & 120 & 90 & 30000 & $270.0^{*}$ & 15.0 \\
\hline & 225 & 180 & 135 & 45000 & $405.0^{*}$ & 22.5 \\
\hline & 300 & 240 & 180 & 60000 & $540.0^{*}$ & 30.0 \\
\hline \multirow{4}{*}{$\begin{array}{l}\text { Organic-mineral pellet-based filter-cake } \\
(\text { OM cake) }\end{array}$} & 60 & 60 & 60 & 500 & 4.5 & 0.3 \\
\hline & 120 & 120 & 120 & 1000 & 9.0 & 0.5 \\
\hline & 180 & 180 & 180 & 1500 & 13.5 & 0.8 \\
\hline & 240 & 240 & 240 & 2000 & 18.0 & 1.0 \\
\hline \multirow{4}{*}{$\begin{array}{l}\text { Organic-mineral pellet-based biochar } \\
\text { (OM biochar) }\end{array}$} & 60 & 60 & 60 & 500 & 4.5 & 0.3 \\
\hline & 120 & 120 & 120 & 1000 & 9.0 & 0.5 \\
\hline & 180 & 180 & 180 & 1500 & 13.5 & 0.8 \\
\hline & 240 & 240 & 240 & 2000 & 18.0 & 1.0 \\
\hline \multirow{4}{*}{$\begin{array}{l}\text { Organic-mineral pellet-based filter-cake } \\
+ \text { humic substances }(\mathrm{OM} \text { cake }+ \text { HS })\end{array}$} & 60 & 60 & 60 & 500 & 4.5 & 0.3 \\
\hline & 120 & 120 & 120 & 1000 & 9.0 & 0.5 \\
\hline & 180 & 180 & 180 & 1500 & 13.5 & 0.8 \\
\hline & 240 & 240 & 240 & 2000 & 18.0 & 1.0 \\
\hline \multirow{4}{*}{ Mineral with polymers (mineral w/pol) } & 60 & 60 & 60 & 375 & 3.3 & 0.2 \\
\hline & 120 & 120 & 120 & 750 & 6.7 & 0.4 \\
\hline & 180 & 180 & 180 & 1125 & 10.1 & 0.6 \\
\hline & 240 & 240 & 240 & 1500 & 13.4 & 0.8 \\
\hline \multirow{4}{*}{ Conventional mineral (mineral) } & 60 & 60 & 60 & 333.33 & 3.0 & 0.2 \\
\hline & 120 & 120 & 120 & 666.66 & 6.0 & 0.3 \\
\hline & 180 & 180 & 180 & 999.99 & 9.0 & 0.5 \\
\hline & 240 & 240 & 240 & 1333.32 & 12.0 & 0.7 \\
\hline
\end{tabular}

Note. Dose applied in g per plant, based on the $\mathrm{N}$ contents (Table 1) present in the raw materials used.

The filter-cake, a by-product of sugarcane activity, was used as an organic base for the formation of organic-mineral and biochar fertilizers.

Sixty days after the limestone application, the fertilizers were applied, and five seeds of maize were cultivated in each pot (cultivar DKB 310 Pro 2). Thinning was carried out at 15 days after sowing (DAS), with only one plant left per pot. At 20 DAS, liquid macro- and micro-nutrient supplementation was performed by adding sulphur, zinc, boron, copper, and manganese $(\mathrm{S}, \mathrm{Zn}, \mathrm{B}, \mathrm{Cu}$, and $\mathrm{Mn}$ ) to the pots in the proportions of $60.0,6.0,2.2,1.5$, and $2.0 \mathrm{~kg} / \mathrm{ha}$, respectively. Throughout the experiment, the irrigation of the pots was constant, with a field capacity of approximately $80 \%$ for all treatments.

At 60 DAS, when the plants had nine fully developed leaves, the plant height $(\mathrm{cm})$, leaf area of the plants $\left(\mathrm{cm}^{2}\right)$, root dry mass $(\mathrm{g})$, and shoot dry mass $(\mathrm{g})$ measures were estimated. The plants were removed, placed in paper bags, and taken to the soil fertility laboratory, where determination of the dry mass of the shoot of the plants (leaves and stems) and roots was conducted using a forced air circulation drying oven at $65{ }^{\circ} \mathrm{C}$.

After determining the dry mass, the samples were ground in a Wiley mill $(2 \mathrm{~mm})$ and stored in paper bags. Subsequently, the macro-nutrient concentrations of the shoot of the plants (Embrapa, 2009) were determined. On the basis of the nutrient content values in the plant and the dry matter mass of the shoot, the accumulation (extraction) of nutrients in the maize plants was calculated by multiplying the dry mass of the shoot (DMS) in $g$ 
by the nutrient content in $\mathrm{g}$ per $\mathrm{kg}$.

On the basis of the plant dry mass values and the use of conventional mineral fertilization as the standard source, the equivalent fertilizer dose was calculated following Equation 1:

$$
\mathrm{Eq}_{\text {Mineral fertilization }}(\%)=\frac{\sum\left[\left(\mathrm{xf}_{180}-\mathrm{xt}\right)+\left(\mathrm{xf}_{240}-\mathrm{xt}\right)\right]}{\sum\left[\left(\mathrm{xk}_{180}-\mathrm{xt}\right)+\left(\mathrm{xk}_{240}-\mathrm{xt}\right)\right]} \times 100 \%
$$

where, $\mathrm{Eq}_{\text {Mineral fertilization }}(\%)$ : equivalent in mineral fertilizer; $\mathrm{xf}_{180}$ : dry matter production of the shoot of the source tested — dose of $180 \mathrm{~kg} / \mathrm{ha} ; \mathrm{xf}_{240}$ : dry matter production from the shoot of the source tested-240 kg/ha dose; $\mathrm{xk}_{180}$ : dry matter production from the shoot of the standard source - dose of $180 \mathrm{~kg} / \mathrm{ha}$; $\mathrm{xk}_{240}$ : dry matter production from the shoot of the standard source $-240 \mathrm{~kg} / \mathrm{ha}$ dose; and xt: dry matter production of the control. The $\mathrm{Eq}_{\text {Mineral fertilization }}(\%)$ calculation is described by Geodert et al. (1986).

To determine the effects of fertilizer application on the soil chemical characteristics after root and plant removal, soil samples were collected from each pot to determine the P and K levels (Embrapa, 2009).

Data were initially tested for residual normality assumptions (the Shapiro-Wilk test), variance homogeneity (Levene's test), and block additivity (Tukey's test for additivity) using the SPSS version 20.0 software. All data were analysed at 0.01 significance level. Later, an analysis of variance was conducted using the statistical software SISVAR (Ferreira, 2011), and the averages were compared using the Scott-Knott (0.05 significance) and Dunnet ( 0.05 significance) tests. To evaluate the effects of fertilizer doses, polynomial regressions were used at a $5 \%$ significance.

\section{Results and Discussion}

The highest values for the DMS were observed when using the mineral fertilizer with polymers and OM cake + HS (Figure 1A). The maximum response points were determined at the doses of 216 and $190 \mathrm{~kg} / \mathrm{ha}$ for the $\mathrm{OM}$ cake + HS and mineral fertilizer with polymers, which corresponded to 33.7 and $33.6 \mathrm{~g}$ of dry mass, respectively (Figure 1A).

Similarly, for the plant height, the highest values were determined when the mineral fertilizer with polymers and OM cake + HS were used. The maximum response values were observed at doses of 180 and $177 \mathrm{~kg} / \mathrm{ha}$ for the mineral fertilizer with polymers and OM cake + HS, respectively (Figure 1B).

The leaf area of the maize plants presented the best results when using the OM cake and OM cake + HS fertilizers. In this treatment, increments with maximum response points were found at the doses of 208 and 258 $\mathrm{kg} / \mathrm{ha}$ for the OM cake and OM cake + HS fertilizers, which correspond to 7465 and $7478 \mathrm{~cm}^{2}$, respectively (Figure 1C). In contrast with these results, Valderrama et al. (2011), upon evaluating the effects of $\mathrm{N}$ and $\mathrm{P}$ doses and sources (coated or not coated with polymers) on the production components of irrigated maize in the Cerrado region, did not find significant differences between the sources with respect to the plant height or stem diameter of maize plants. The best results observed for the OM cake and OM cake + HS treatments may be explained by the gradual release of both fertilizers, which provide a more adequate nutrition for maize plants. 


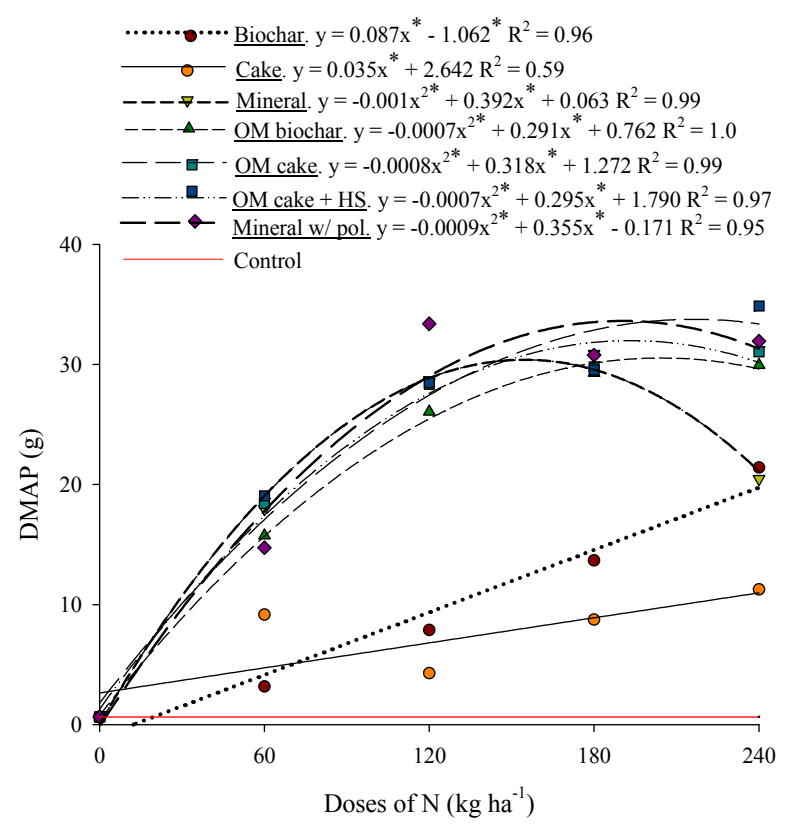

A

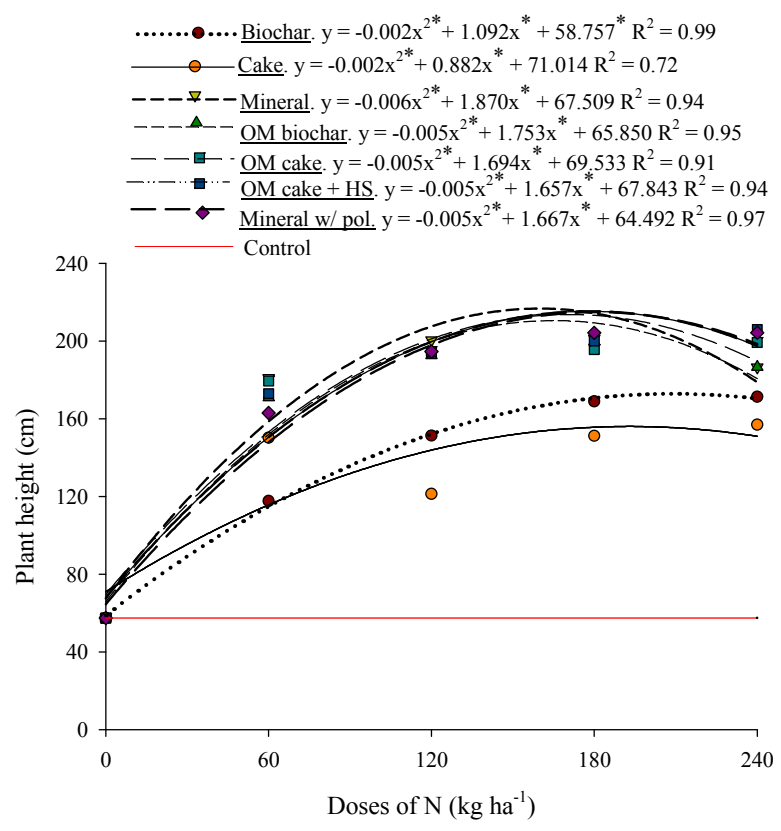

B

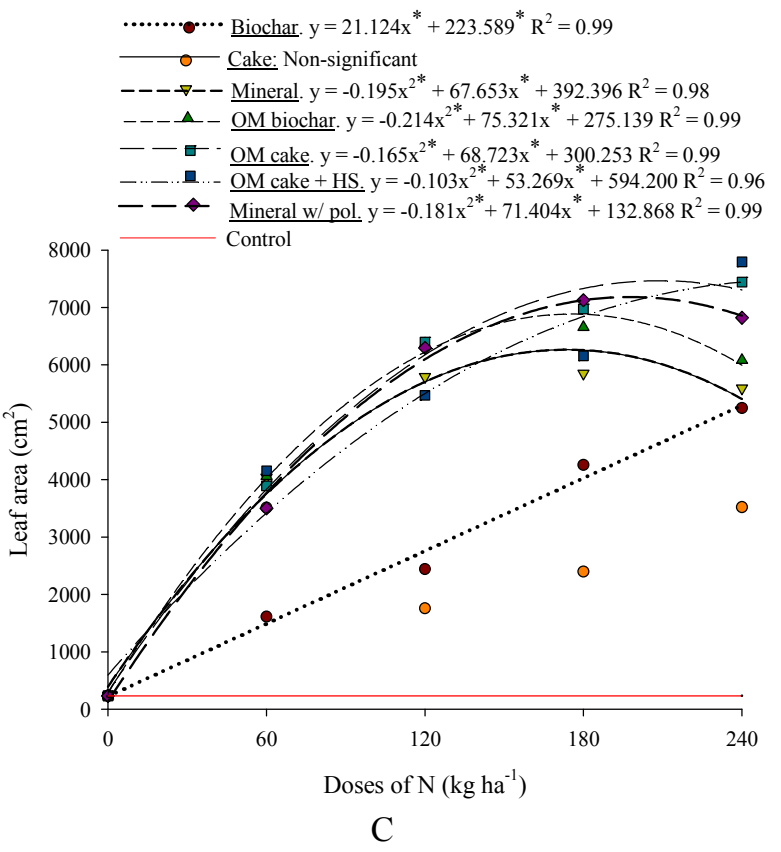

Figure 1. Dry matter mass of the shoot of the plant_DMAP $(\mathrm{g})(\mathrm{A})$; Height $(\mathrm{cm})(\mathrm{B})$ and leaf area $\left(\mathrm{cm}^{2}\right)(\mathrm{C})$ in maize plants under different fertilizers and doses of $\mathrm{N}(\mathrm{kg} / \mathrm{ha}) 60$ days after sowing. Red lines refer to the value of the control, in which no fertilizer was applied to the soil

A greater efficiency was observed for treatments with the OM cake, OM biochar, OM cake + HS, and mineral

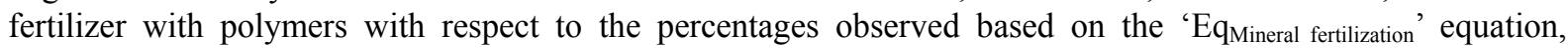
relative to the equivalent values of each product in relation to the mineral fertilizer. For the cake and biochar fertilizers, a reduction in efficiency was observed when compared to the mineral fertilizer (Table 3). These results demonstrate that the protection against loss factors (volatilization, fixation, and leaching) and the gradual release provided by organic-mineral and mineral fertilizers with polymers played a fundamental role in the greater efficiency of these treatments. Thus, strategies aimed at the application of lower doses of these fertilizers 
can be used in the field without the risk of productivity losses, whilst maintaining the profitability for the producer.

Table 3. Equivalent values and efficiency of different types of fertilizers compared to a standard mineral fertilizer

\begin{tabular}{lll}
\hline Source & Equivalent in mineral fertilizer* (\%) & Efficiency (\%) \\
\hline OM cake & 118.97 & 18.97 \\
OM biochar & 115.71 & 15.71 \\
OM cake + HS & 126.04 & 26.04 \\
Cake & 37.40 & -62.60 \\
Mineral w/ pol & 122.70 & 22.70 \\
Biochar & 67.49 & -32.51 \\
\hline
\end{tabular}

Note. Calculations were performed according to the efficiency equation $\left(\mathrm{Eq}_{\text {Mineral fertilization }}\right)$ based on the applied doses of mineral fertilizer.

Regarding the accumulated $\mathrm{N}$ and $\mathrm{K}$ contents, it was observed that the OM cake, OM biochar, OM cake + HS, and mineral fertilizer with polymers at a dose of $240 \mathrm{~kg} / \mathrm{ha}$ presented the best results (Figure 2). For these treatments, the accumulated $\mathrm{N}$ content in the shoot of the plant increased linearly, and every $10 \mathrm{~kg}$ of nutrients applied to the soil increased the $\mathrm{N}$ content by $38.9,38.1,41.5$, and $36.4 \mathrm{mg} /$ pot with the OM cake, OM biochar, $\mathrm{OM}$ cake $+\mathrm{HS}$, and mineral fertilizer with polymers, respectively (Figure 2A).

As for the $\mathrm{K}$ content accumulated in the shoot, it was found that every $10 \mathrm{~kg}$ of nutrients applied to the soil increased the K content by $59.8,56.0,63.6$, and $60.0 \mathrm{mg} / \mathrm{pot}$ with the OM cake, OM biochar, OM cake + HS, and mineral with polymers treatments, respectively (Figure 2B).

Unlike the results obtained in the current study, when evaluating the effectiveness of a polymer-coated $\mathrm{K}$ fertilizer compared to conventional $\mathrm{KCl}$ on maize plant nutrition in two soil types (sandy and clayey), Bley (2015) found that independent of the soil and doses, $\mathrm{K}$ absorption was higher in plants under the conventional treatment compared to those given the coated- $\mathrm{KCl}$ treatment.

When the accumulated P content in the maize plants was analyzed, it was found that the OM cake, OM cake + HS, and mineral fertilizer with polymers, at a dose of $240 \mathrm{~kg} / \mathrm{ha}$, presented the highest values. Linear increases were observed as the applied dose to the soil increased; for every $10 \mathrm{~kg}$ of nutrients applied, there was an increase in the $\mathrm{P}$ of $7.3,6.4$, and $6.8 \mathrm{mg} /$ pot for the OM cake, OM cake + HS, and mineral fertilizer with polymers, respectively (Figure 2C). 


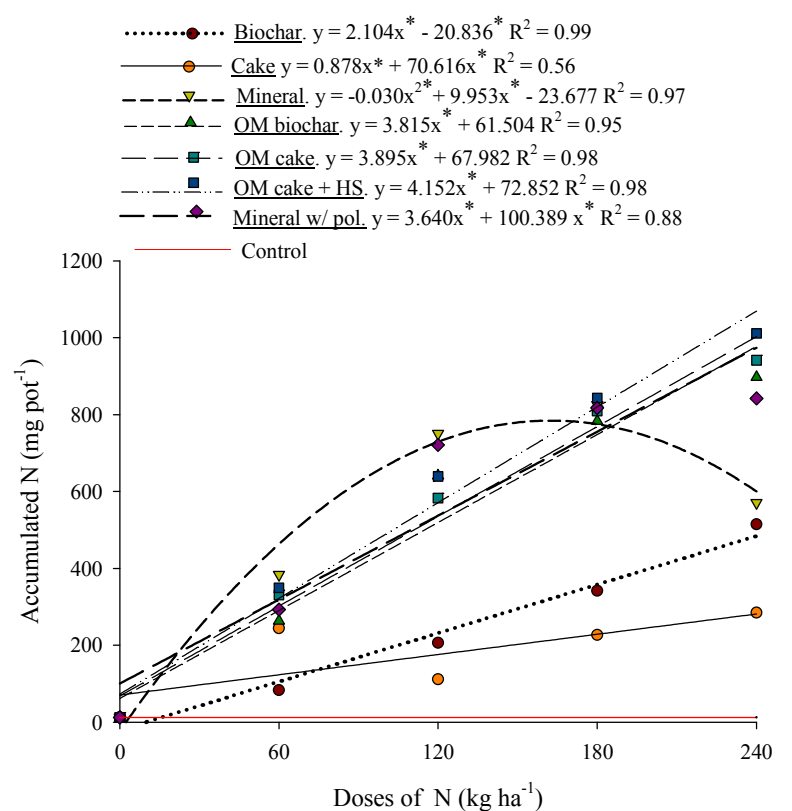

A

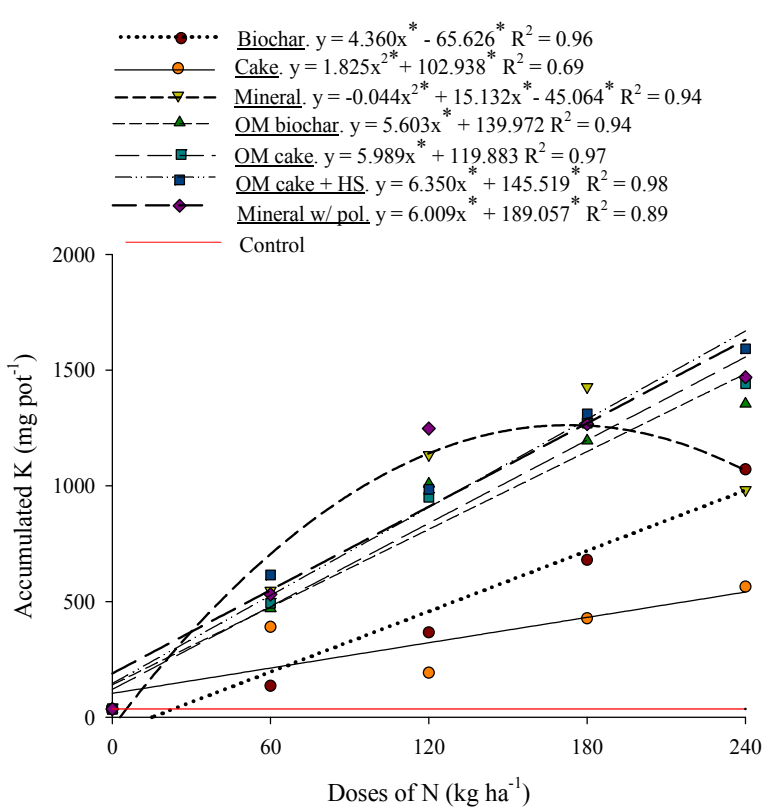

$\mathrm{B}$

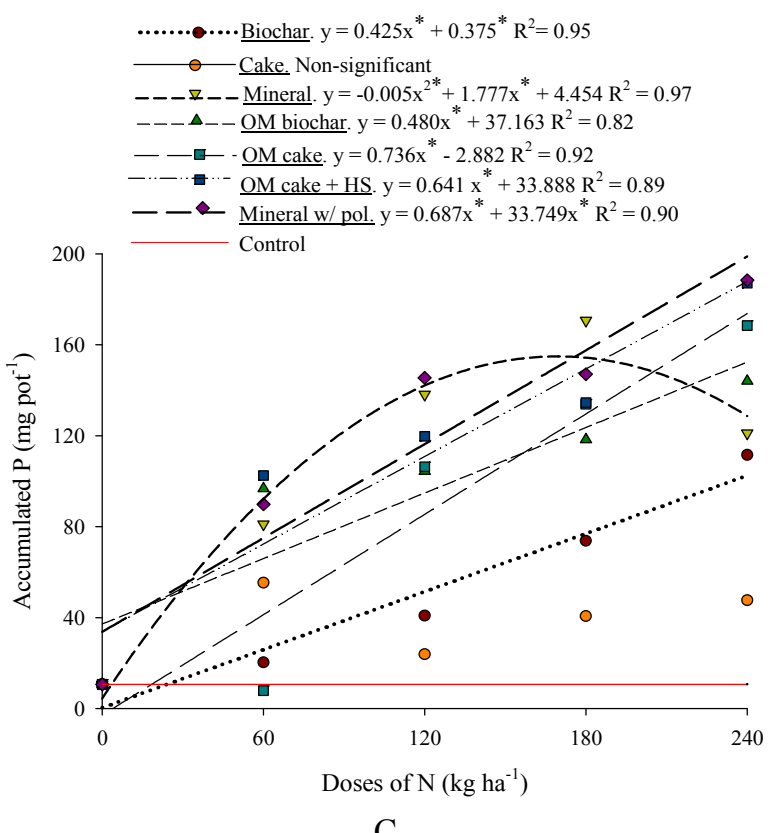

Figure 2. Nitrogen-N (A), Potassium-K (B), and Phosphorus-P (C) accumulated in the shoot of maize plants (mg/pot) under different fertilizers and doses of $\mathrm{N}(\mathrm{kg} / \mathrm{ha}) 60$ days after sowing. Red lines refer to the value of the control, in which no fertilizer was applied to the soil

According to Pinton et al. (1999), the beneficial effects of humic substances on plant nutrition are linked to better root development. Moreover, humic substances increase the emergence of lateral roots in the plant, which induces the production of smaller but more branched secondary roots, thus improving the absorption of nutrients by the plant (Canellas et al., 2002). Therefore, the higher accumulation of N, P, and K in the shoot of the maize plants when the OM cake + HS treatment was applied may be related to better absorption efficiency of these nutrients, due to the addition of organic acids to the organic-mineral fertilizer.

There was no significant difference in the soil $\mathrm{P}$ content with most of the fertilizers studied, when compared to the control, except for the $120 \mathrm{~kg} / \mathrm{ha}$ dose of filter-cake and the 180 and $240 \mathrm{~kg} / \mathrm{ha}$ doses of biochar (Figure $3 \mathrm{~A}$ ). 
The highest values for the residual P content in the soil were obtained when applying the organic filter-cake and biochar fertilizers. The $\mathrm{P}$ content in the soil was adjusted to a quadratic equation for the filter-cake organic compost, with the maximum value at a dose of $137 \mathrm{~kg} / \mathrm{ha}$, which corresponded to $36.23 \mathrm{mg} / \mathrm{dm}^{3}$. Regarding the biochar treatment, the highest value for this variable was observed when the fertilizer was applied at a dose of $240 \mathrm{~kg} / \mathrm{ha}$. For each $10 \mathrm{~kg}$ of fertilizer applied, there was an increase of $1.1 \mathrm{mg} / \mathrm{dm}^{3}$ in the $\mathrm{P}$ in the soil (Figure $3 \mathrm{~A})$.

The higher residual $\mathrm{P}$ content in the soil, resulting from the application of organic fertilizers, can be explained by the decreased adsorption of this element in the soil colloids, provided by the application of organic matter. Regarding the residual $\mathrm{K}$ levels in the soil, it was observed that regardless of the treatment used, there were linear increases in the content of this element with the application of higher dosages of fertilizers to the soil (Figure 3B).

Considering the mineral fertilizer, it was observed that compared with the applied dose of $180 \mathrm{~kg} / \mathrm{ha}$, all applied fertilizers showed a significant difference in the $\mathrm{K}$ levels of the soil for, except for the organic compound biochar and filter-cake, in which the results were superior to the control even at lower dosages (Figure 3B).

The highest $\mathrm{K}$ content in the soil was obtained when biochar and filter-cake were applied, where for each $10 \mathrm{~kg}$ of nutrients applied to the soil there was an increase of 15.4 and $15.11 \mathrm{mg} / \mathrm{dm}^{3}$ for biochar and filter-cake, respectively (Figure 3B).

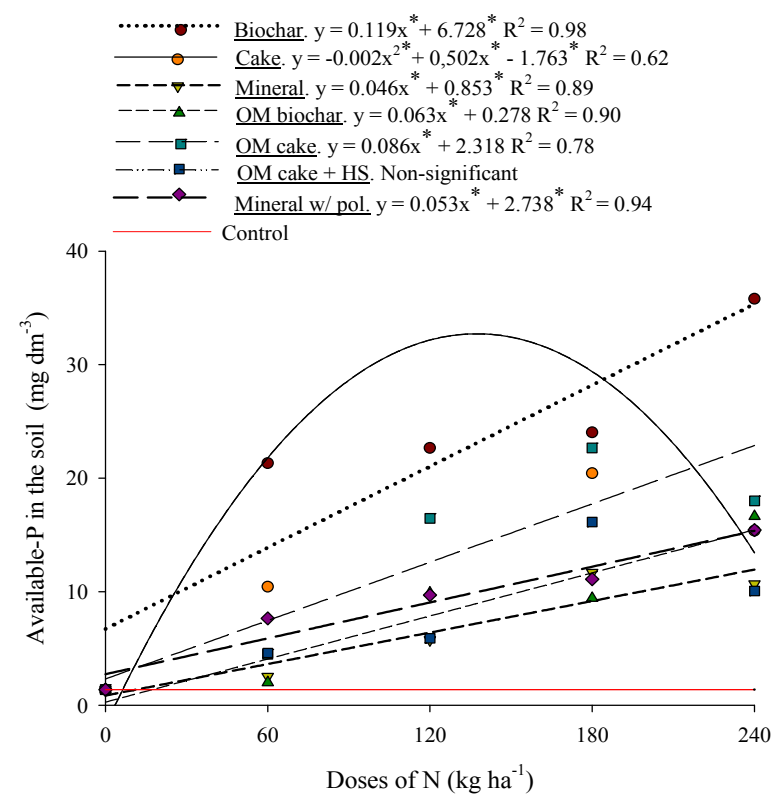

A

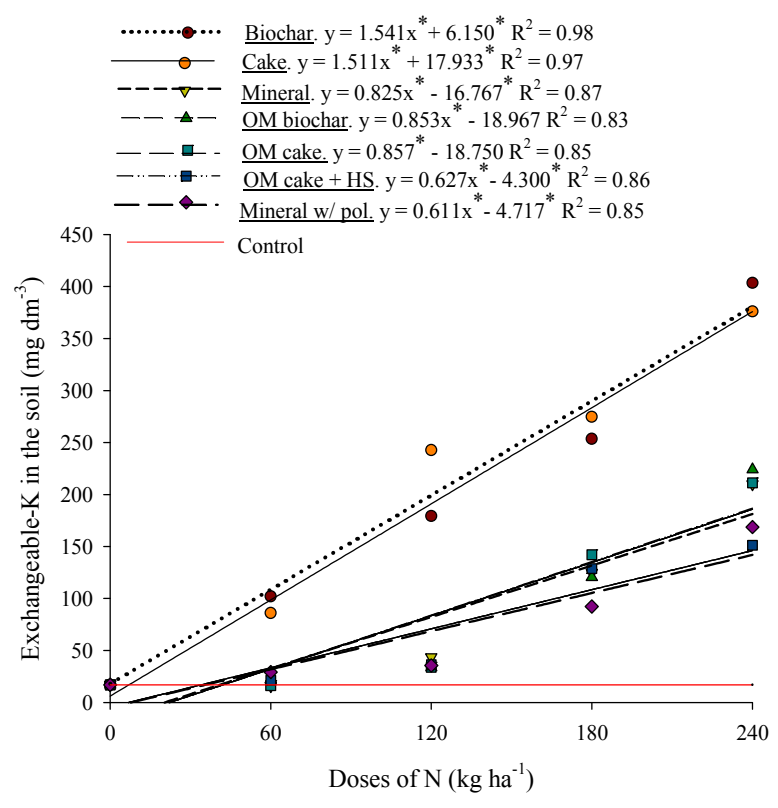

B

Figure 3. Phosphorus-P (Mehlich-1) (A) and Potassium-K (B) contents in the soil $\left(\mathrm{mg} / \mathrm{dm}^{3}\right)$ as a function of increasing doses of $\mathrm{N}$ rates $(\mathrm{kg} / \mathrm{ha})$ using different fertilizers. Red lines refer to the value of the control, in which no fertilizer was applied to the soil

Similar results to the current investigation were obtained by Junior et al. (2011), when studying the effects of different doses of organic and mineral fertilizers on sugarcane and soil chemical attributes. They verified significant increases in the soil $\mathrm{P}$ content when compared to the use of mineral fertilizer, thus indicating the efficiency of the compound to supply $\mathrm{P}$ to the soil. The same occurred for $\mathrm{K}$ in the soil, where increasing doses of cake provided significant increments in the content of this element in the soil.

\section{Conclusion}

Mineral fertilizers with polymers, OM cake + HS, and OM cake were the most efficient in increasing the growth of maize plants.

The OM cake + HS fertilizer was revealed as the most efficient for the maize crop, and it was able to replace the mineral fertilizer, by demonstrating up to $26 \%$ greater efficiency in the production of the dry mass of the plants. 
The accumulation of $\mathrm{N}, \mathrm{P}$, and $\mathrm{K}$ was higher in the shoot of maize plants when the OM cake $+\mathrm{HS}$, mineral fertilizer with polymers, and OM cake were applied.

The treatments based on filter-cake and biochar produced better results for the $\mathrm{P}$ content and residual $\mathrm{K}$ in the soil.

\section{References}

Benites, V. N., Correa, J. C., Menezes, J. F. S., \& Polidoro, J. C. (2010). Produção de fertilizante organomineral granulado a partir de dejetos de suinos e aves no Brasil. Congresso FertBio 4, Anais... Guarapari-ES.

Bley, H. (2015). Liberação, nutrição de plantas e lixiviação de potássio de fertilizante revestido (68f., Dissertação (Mestrado em ciência do solo), Universidade Federal de Santa Maria, Porto Alegre, RS, Brasil).

Canellas, L. P., Oliavres, F. L., Façanha, A. L. O., \& Façanha, A. R. (2002). Humic acids isolated from earthworm compost enhance rootelongation, lateral root emergence and plasma membrane $\mathrm{H}+-$ ATPase activity in maize root. Plant Physiol, 130, 1951-1957. https://doi.org/10.1104/pp.007088

EMBRAPA (Empresa Brasileira de Pesquisa Agropecuária). (2009) Manual de análises químicas de solos, plantas e fertilizantes (2nd ed., p. 628). Informação Tecnológica, Brasília.

EMBRAPA (Empresa Brasileira de Pesquisa Agropecuária). (1997). Manual de métodos de análise de solo (2nd ed., p. 212). EMBRAPA-CNPS, Rio de Janeiro, RJ.

Ferreira, D. F. (2011). Sisvar: A computer statistical analysis system. Ciência e Agrotecnologia, 35(6), 1039-1042. https://doi.org/10.1590/S1413-70542011000600001

Junior, A. B. A., Nascimento, C. W. A., Sobral, M. F., Silva, F. B. V., \& Gomes, W. A. (2011). Fertilidade do solo e absorção de nutrientes em cana-de-acucar fertilizada com torta de filtro. Revista Brasileira Engenharia Agricola Ambiental, 15(10), 1004-1013. https://doi.org/10.1590/S1415-43662011001000003

Geodert, W. J., Souza, D. M. G., \& Rein, T. A. (1986). Princípios metodológicos para avaliação agronômica de fontes de fosforo (Documentos 22, p. 23). Planaltina, DF: EMBRAPA.

Nannipieri, P., Muccini, L., \& Ciardi, C. (1983). Microbial Biomass and Enzyme Activities: Production and Persistence. Soil Biology and Biochemistry, 15, 679-685. https://doi.org/10.1016/0038-0717(83)90032-9

Pinton, R., Cesco, S., Lacolettig, G., Astolfi, S., \& Varanini, Z. (1999). Modulation of $\mathrm{NO}_{3}^{-}$uptake by water-extractable humic substances: Involvement of root plasma mebranes H+ ATPase. Plant and Soil, 215, 155-161. https://doi.org/10.1023/A:1004752531903

Polidoro, J. C. (2013). Fertilizantes Organominerais: Aspectos Mercadológicos e Tecnológicos-Rede FertBrasil. Ribeirão Preto, São Paulo, Brasil: V Fórum Abisolo.

Rocha, J. C., \& Rosa, A. H. (2003). Substâncias húmicas aquáticas: interações com espécies metálicas (p. 120). São Paulo, UNESP.

Silva, A. A., Silva, T. S., Vasconcelos, A. C. P., \& Lana, R. M. Q. (2012). Aplicação de diferentes fontes de ureia de liberação gradual na cultura do milho. Bioscience Journal, 28, 104-111.

Van Zwieten, L., Kimber, S., Morris, S., Chan, K. Y., Downie, A., Rust, J., ... Cowie, A. (2010). Effects of biochar from slow pyrolysis of papermill waste on agronomic performance and soil fertility. Plant Soil, 327, 235-246. https://doi.org/10.1007/s11104-009-0050-x

Valderrama, M., Buzetti, S., Benett, C. G. S., Andreotti, M., \& Filho, M. C. M. T. (2011). Fontes e doses de NPK em milho irrigado sob plantio direto. Pesquisa Agropecuária Tropical, 41(2), 254-263. https://doi.org/ 10.5216/pat.v41i2.8390

\section{Copyrights}

Copyright for this article is retained by the author(s), with first publication rights granted to the journal.

This is an open-access article distributed under the terms and conditions of the Creative Commons Attribution license (http://creativecommons.org/licenses/by/4.0/). 